\title{
Pain in the Separation of Molars among the Orthodontic Patients
}

*Pushkar Manandhar ${ }^{1}$, Anjana Rajbhandari ${ }^{2}$, Resina $\operatorname{Pradhan}^{1}$, Manju Bajracharya ${ }^{1}$, Surendra Maharjan ${ }^{1}$

\section{Authors Info:}

${ }^{1}$ Assistant Professor, ${ }^{2}$ Professor

Department of Orthodontics and Dentofacial Orthopedics, People's Dental College and Hospital, Sorhakhutte, Kathmandu

${ }^{*}$ Corresponding Author:

Dr. Pushkar Manandhar; Contacts: dr.pushkar. manandhar@gmail.com +977-9841489384

Disclaimer:

Conflict of Interest: None Source of Support: None Copyright $\odot 2019$ by author(s), licensed under the Creative Commons Attribution International License 4.0.

\section{ABSTRACT:}

Introduction: Pain has been the most common and foremost reason for discontinuing the orthodontic treatment. The patients usually experience the pain in Orthodontic treatment during separator placement, wire placement, headgear wear, and rapid palatal expansion. Placement of orthodontic separators (brass wire, elastomeric, spring type steel separators, and latex elastics) results in a painful experience. Therefore the purpose of the study is to assess the pain perception among the patients seeking orthodontic treatment.

Methods: This study was carried out amongst 120 (53 male and 67 female) patient seeking orthodontic treatment. Elastomeric separators was placed mesially and distally to the first molars and the participants was given self-administrated Universal pain assessment Tool to document perceived pain and pain upon chewing, using a visual analog scale for seven days. Total scores were calculated and a descriptive statistics in the form of number (mean) and percentage were calculated.

Results: This study showed a mean score for perceived pain of each day to be $7.16,7.1,6.05,4.67,3.69,2.88$, and 2.27 respectively with mean of $4.831+/$ 1.273. Similarly the mean score for pain on chewing were 8.21, 7.53, 6.62, 5.19, $4.38,3.65$, and 3 with mean of $5.5119+/-1.269$.

Conclusions: There was significant difference on pain perception among the male and female participants, female having higher pain perception. There was significant difference in pain perception between the Adolescent and Adult in both normal life and during eating.

Keywords: Pain, Separators, Universal Pain Assessment Tool

\section{Article Info}

Received: October 26, 2019

Accepted: November 18, 2019

Published Online: December 16, 2019

How to cite this article in Vancouver Style?

Manandhar P, Rajbhandari A, Pradhan R, Bajracharya M, Maharjan S. Pain Assessment in separation of the Molar among the Orthodontic Patients. Europasian J Med Sci 2019;1(1):48-52. https://doi.org/10.46405/ejms.vli1.13
Access this article online

Publisher Note:

The Europasian Journal of Medical Sciences (EJMS) is an official Journal of Nirvana Psychosocial Care Center \& Ressearch Institute www.nirvanapscc.com. The Journal as well as publisher remain neutral with regards to any jurisdictional claims in any published articles, its contents and the institutional affiliations of the authors.

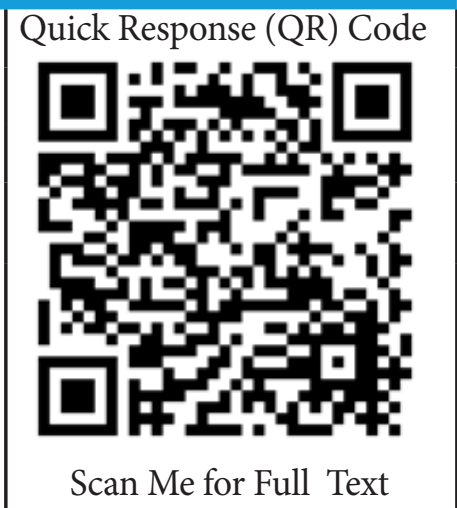




\section{INTRODUCTION}

Tnternational Association for The Study of Pain (IASP) has defined Pain as an unpleasant sensory and emotional experience associated with actual or potential tissue damage, or described in terms of such damage. Pain has been the most common and foremost reason for discontinuing the orthodontic treatment. The patients usually experience the pain in Orthodontic treatment during separator placement, wire placement, headgear wear, and rapid palatal expansion. ${ }^{1-4}$

The cause for the sensation of pain is mainly due to release of various biochemical mediators which are stimulated by inflammatory reactions in periodontium and dental pulp during the orthodontic tooth movement. The pain is due to changes in blood flow caused by the appliances which is correlated with the release and presence of various substances, such as Substance-P, Histamine, enkephalin, dopamine, serotonin, cytokines, etc. Many literatures regarding the increase in the levels of these mediators, which elicit hyperalaesia response following force application, has been published in Orthodontics. ${ }^{5,6}$

Placement of orthodontic separators (brass wire, elastomeric, spring type steel separators, and latex elastics) results in a painful experience. Two controlled clinical trials ${ }^{7,8}$ performed by Ngan et al. concluded that there was discomfort associated with separator placement, which usually starts within 4 hours of insertion. The level of discomfort increases over the next 24 hours and decreases to pre-placement level within 7 days. Bondemark et al. ${ }^{9}$ has evaluated and compared the separation effect and patient perception of pain and discomfort to two types of orthodontic separators (elastomeric and spring type) but found no statistically significant difference between the discomfort caused by the two types of separators. They reported that the worst pain was experienced at day 2 and subsided almost completely by day 5 . An electromyographic (EMG) study by Michelotti et al. ${ }^{10}$, performed to evaluate the motor and sensory changes associated with separator placement, showed a decrease in motor output as well as pressure pain threshold in muscles of mastication.

Thus the pain assessment during the placement of separators in orthodontic procedure amongst the Nepalese patient would be necessary for the management of the pain.

\section{MATERIALS AND METHODS}

The total number of 120 (53 male and 67 female) patients, (convenient sampling) who visited different hospitals and clinics in Kathmandu, Nepal seeking for orthodontic treatment during 4 months of period, were informed about their participation in the research and the written informed consent was obtained after getting ethical clearance from Institutional Review Committee, Maharajgunj, Nepal.

\begin{tabular}{|l|l|l|}
\multicolumn{1}{|c|}{ Gender } & Frequency & \multicolumn{1}{c|}{ Percent } \\
\hline Female & 67 & 55.8 \\
\hline Male & 53 & 44.2 \\
\hline Total & 120 & 100 \\
\hline Age & Frequency & Percent \\
\hline Teenager & 68 & 56.7 \\
\hline Adult & 52 & 43.3 \\
\hline Total & 120 & 100 \\
\hline
\end{tabular}

Table 1: Frequency distribution by age and gender

On the first visit of the orthodontic treatment of the patient, the elastomeric separators were placed on the mesial and distal of the first molars. Then the patients were given a self-administered Universal pain assessment Tool (fig. 1), with 1 to 10 markings to take home. Then the participants were asked to mark the intensity of the pain they perceived every day for next 7 days, 1 being no pain and 10 being the upmost pain. They were also asked to mark the Universal pain assessment tool for perceived pain on chewing.

The data thus obtained were analyzed at the significance level of 0.05 . The data were compared between male and female and between the different age groups too.

\section{Universal Pain Assessment Tool}

This pain assessment tool is intended to help patient care providers access pain according to individual patient needs. Explin and use 0-10 Scale for patient self-assessment. Use the faces or behavorial observations to interpret

\begin{tabular}{lllllllllll}
0 & 1 & 2 & 3 & 4 & 5 & 6 & 7 & 8 & 9 & 10 \\
\hline & 1 & 1 & & 1 & & & & &
\end{tabular}

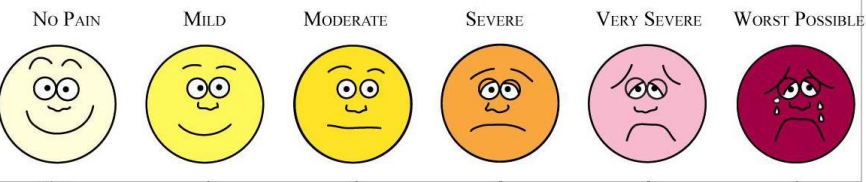

Fig. 1. Universal pain Assessment tool 22 


\section{RESULTS}

The entire self-administered Universal Assessment tool were collected from 120 participants. The results of mean score for perceived pain of each day were 7.16, $7.1,6.05,4.67,3.69,2.88$, and 2.27 respectively with mean of $4.831+/-1.273$. Similarly the mean score for pain on chewing were $8.21,7.53,6.62,5.19,4.38,3.65$, and 3 with mean of $5.5119+/-1.269$.

\begin{tabular}{|c|c|c|c|c|c|}
\hline Days & $\begin{array}{c}\text { Frequ } \\
\text {-ency }\end{array}$ & $\begin{array}{c}\text { Mini. } \\
\text { Pain } \\
\text { Grade }\end{array}$ & $\begin{array}{c}\text { Max. } \\
\text { Pain } \\
\text { Grade }\end{array}$ & Mean & S.D. \\
\hline Day1 & 120 & 5 & 9 & 7.16 & 1.264 \\
\hline Day2 & 120 & 3 & 9 & 7.1 & 1.959 \\
\hline Day3 & 120 & 2 & 9 & 6.05 & 1.699 \\
\hline Day4 & 120 & 2 & 8 & 4.67 & 1.712 \\
\hline Day5 & 120 & 1 & 8 & 3.69 & 1.608 \\
\hline Day6 & 120 & 1 & 7 & 2.88 & 1.278 \\
\hline Day7 & 120 & 0 & 7 & 2.27 & 1.179 \\
\hline
\end{tabular}

Table 2: Descriptive analysis of regular life dental pain

\begin{tabular}{|l|l|l|l|l|l|}
\hline Days & $\begin{array}{c}\text { Frequ } \\
\text {-ency }\end{array}$ & $\begin{array}{c}\text { Mini. } \\
\text { Pain } \\
\text { Grade }\end{array}$ & $\begin{array}{c}\text { Max. } \\
\text { Pain } \\
\text { Grade }\end{array}$ & Mean & S.D. \\
\hline Day1 & 120 & 6 & 9 & 8.21 & 0.829 \\
\hline Day2 & 120 & 3 & 9 & 7.53 & 1.782 \\
\hline Day3 & 120 & 2 & 9 & 6.62 & 1.745 \\
\hline Day4 & 120 & 2 & 9 & 5.19 & 1.755 \\
\hline Day5 & 120 & 2 & 9 & 4.38 & 1.583 \\
\hline Day6 & 120 & 1 & 8 & 3.65 & 1.436 \\
\hline Day7 & 120 & 0 & 22 & 3 & 2.177 \\
\hline
\end{tabular}

Table 3: Descriptive analysis of during eating daily dental pain

This shows there is increased pain during eating with the separator in the teeth. The pain perception pattern showed that the participant had the upmost pain for the first 3 days and it gradually decreased after that.

The independent T-test showed that there was significant difference on pain perception among the male and female participants, female having higher pain perception.

\begin{tabular}{|l|l|l|l|l|l|l|}
\hline Characteristics & Gender & Frequency & Mean & S.D. & t & Sig(2-tailed) \\
\hline \multirow{2}{*}{ During Eating Mean } & Male & 53 & 5.0108 & 1.3485 & -3.978 & 0.000 \\
\cline { 2 - 6 } & Female & 67 & 5.9083 & 1.0541 & & \\
\hline \multirow{2}{*}{ Regular Mean } & Male & 53 & 4.3127 & 1.3924 & -4.086 & \multirow{2}{*}{0.000} \\
\cline { 2 - 6 } & Female & 67 & 5.2409 & 1.0038 & & \\
\hline
\end{tabular}

Table 4: Analysis of gender with regular and during eating dental pain

The participants were divided into two groups according to the age, 12-16 years (adolescent) and 16-24years (adult). The mean pain perception of Adolescent was 5.1087 and that of adults was 4.3736. Similarly, the mean pain perception of Adolescent during eating was 5.7794 and for Adult during eating were 5.1621.

\begin{tabular}{|l|l|l|l|l|l|l|}
\hline Characteristics & Age & Frequency $(\mathrm{n})$ & Mean & Std. Deviation & t-Test & Sig(2-tailed) \\
\hline \multirow{2}{*}{ During Eating Mean } & Adolescent & 68 & 5.7794 & 1.0142 & 2.581 & 0.012 \\
\cline { 2 - 7 } & Adult & 52 & 5.1621 & 1.4792 & & \\
\hline \multirow{2}{*}{ Regular Mean } & Adolescent & 68 & 5.1807 & 1.0094 & 3.45 & 0.001 \\
\cline { 2 - 6 } & Adult & 52 & 4.3736 & 1.4373 & & \\
\hline
\end{tabular}

Table 5: Analysis of age with regular and during eating dental pain

This showed there is significant difference between the Adolescent and Adult in both normal life and during eating. 


\section{DISCUSSION}

$\mathrm{T}$ he results obtained from the research using Universal Pain Assessment Tool for pain perception suggest the patient experiences pain during separator placement. The management of the pain can be done by the use of NSAIDS, anesthetic gel ${ }^{11}$, application of continuous wave low-level laser therapy ${ }^{12}$, and the use of vibratory stimulation. ${ }^{13}$

The current study showed there is increased pain during eating with the separator in the teeth. Bondmark et al. ${ }^{9}$, and Scheurer et al. ${ }^{14}$ also showed that eating is most affected activity during separator placement.

The pain perception pattern showed that the participant had the upmost pain for the first 3 days, Day 1 being the most and it gradually decreased after that. This result showed the agreement with the studies done by Ngan et al. ${ }^{7,8}$, Giannopoulou et al. ${ }^{15}$, and Wilson et al. ${ }^{16}$ In contrary to that Bondmark et al. ${ }^{9}$ and Cureton et al. ${ }^{17}$ showed the highest pain perception on Day 1 and Day 3 respectively.

From the statistics of the study, it can be said that there is significant difference in pain perception among the genders. It shows female experiences pain more than male. This result goes in accordance with the results of research done by Abu Alhaija et al. ${ }^{18}$, Krishnan et al. ${ }^{19}$, and Berguis et al. ${ }^{20}$ However, the study conducted by Abdullah showed no significant difference between male and female. ${ }^{21}$

It was also shown that there was significant difference between adults and Adolescent. Adults were shown more tolerant to pain by the separators than the adults which is obvious. But the study done by Ngan et al. ${ }^{7,8}$ disagrees with this result claiming the pain perception levels were same for adults and adolescences.

\section{CONCLUSION}

$\mathrm{T}$ hus it can be concluded that there is a pain due to separator placement during orthodontic treatment with maximum pain on the first day which declines after Day 3 gradually. The Adolescents and female has less tolerance to the pain than the adults and male.

Acknowledgement: The entire orthodontic patients involved in the study are acknowledged for making the study fruitful.

\section{REFERENCES}

1. Firestone AR, Scheurer PA, Bürgin WB. Patients' anticipation of pain and pain-related side effects, and their perception of pain as a result of orthodontic treatment with fixed appliances. Eur J Orthod. 1999;21:387-96. https://doi.org/10.1093/ejo/21.4.387 $\underline{\text { Google Scholar } \mid \text { CrossRef } \mid \text { PubMed }}$

2. Cureton SL. Headgear and pain. J Clin Orthod. 1994;28:525-30. Full Text

3. Needleman HL, Hoang CD, Allred E, Hertzberg J, Berde C. Reports of pain by children undergoing rapid palatal expansion. Pediatr Dent. 2000;22:221-6.

$\underline{\text { Google Scholar | Full Text }}$

4. Sergl HG, Klages U, Zentner A. Pain and discomfort during orthodontic treatment: Causative factors and effects on compliance. Am J Orthod Dentofacial Orthop. 1998;114:684-91. https://doi.org/10.1016/ S0889-5406(98)70201-X

Google Scholar | CrossRef | PubMed

5. Yamasaki k, Shibata Y, Imai S, Tani Y, Shibasaki Y, Fukuhara T. Clinical application of prostaglandin E1 (PGE1) upon orthodontic tooth movement. Am J Orthod. 1984;85(6):508-18. https://doi. org/10.1016/0002-9416(84)90091-5

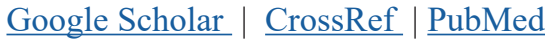

6. Davidovitch Z, Nicolay OF, Ngan PW, Shanfeld JL. Neurotransmitters, cytokines, and the control of alveolar bone modeling in orthodontics. Dent Clin North Am. 1988 Jul;32(3):411-35

$\underline{\text { Google Scholar | Full Text }}$

7. Ngan P, Kess B, Wilson S. Perception of discomfort by patients undergoing orthodontic treatment. Am J Orthod Dentofacial Orthop. 1989; 96:47-53. https:// doi.org/10.1016/0889-5406(89)90228-X

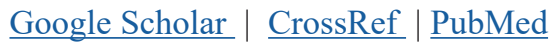

8. Ngan P, Wilson S, Shanfeld J, Amini H. The effect of ibuprofen on the level of discomfort in patients undergoing orthodontic treatment. Am J Orthod Dentofacial Orthop. 1994; 106:88-95. https://doi. org/10.1016/S0889-5406(94)70025-7

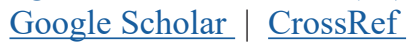

9. Bondemark L, Fredriksson K, Ilros S. Separation effect and perception of pain and discomfort from two types of orthodontic separators. World J Orthod. 2004;5:172-6. Google Scholar | Full Text 
10. Michelotti A, Farella M Martina R Sensory and motor changes of the human jaw muscles during induced orthodontic pain. Eur J Orthod 1999; 21:197-404. https://doi.org/10.1093/ejo/21.4.397

11. Keim RG. Managing orthodontic pain. J Clin Orthod. 2004;38:641-2. Google Scholar | PubMed

12. Eslamian L, Borzabadi-Farahani A, Hassanzadeh-Azhiri A, Badiee MR, Fekrazad R. The effect of 810-nm low-level laser therapy on pain caused by orthodontic elastomeric separators. Lasers Med Sci. 2014;29:559-64. https://doi.org/10.1007/s 10103-012-1258-1 Google Scholar | CrossRef | PubMed

13. Marie SS, Powers M, Sheridan JJ. Vibratory stimulation as a method of reducing pain after orthodontic appliance adjustment. J Clin Orthod. 2003;37:205-8. Google Scholar | PubMed

14. Scheurer PA, Firestone AR, Bürgin WB. Perception of pain as a result of orthodontic treatment with fixed appliances. Eur J Orthod. 1996;18:34957. https://doi.org/10.1093/ejo/18.1.349 Google Scholar $\mid$ CrossRef $\mid$ PubMed

15. Giannopoulou C, Dudic A, Kiliaridis S. Pain discomfort and crevicular fluid changes induced by orthodontic elastic separators in children. J Pain. 2006;7:367-76. https://doi.org/10.1016/j. jpain.2005.12.008 [Google Scholar] | CrossRef PubMed

16. Wilson S, Ngan P, Kess B. Time course of the discomfort in young patients undergoing orthodontic treatment. Pediatr Dent. 1989;11:107-10. Google Scholar | PubMed

17. Cureton SL, Bice RW. Comparison of three types of separators in adult patients. J Clin Orthod. 1997;31:172-7. Google Scholar | PubMed

18. Abu Alhaija ES, Aldaikki A, Al-Omairi MK, AlKhateeb SN. The relationship between personality traits, pain perception and attitude toward orthodontic treatment. Angle Orthod. 2010;80:11419. https://doi.org/10.2319/012710-59.1 CrossRef | PubMed

19. Krishnan V. Orthodontic pain: From causes to management - A review. Eur J Orthod. 2007;29:1709. https://doi.org/10.1093/ejo/cj1081
20. Bergius M, Berggren U, Kiliaridis S. Experience of pain during an orthodontic procedure. Eur J Oral Sci. 2002; 110:92-8.

https://doi.org/10.1034/j.1600-0722.2002.11193.x

21. Abdullah M. Intensity of pain due to separators in adolescent orthodontic patients. J Orthod Sci. 2015;4(4):118-122. https://doi.org/10.4103/2278$\underline{0203.173423} \underline{\text { Google Scholar }}|\underline{\text { CrossRef }}|$ PubMed

22. Dugashvili G, Van den Berghe L, Menabde G, Janelidze M, Marks L. Use of the universal pain assessment tool for evaluating pain associated with TMD in youngsters with an intellectual disability. Med Oral Patol Oral Cir Bucal. 2017 Jan 1;22 (1):e88-94). Google Scholar | Full Text 